\title{
Problematické tranzice k mateřství 1
}

\section{Problematic transition to motherhood}

\author{
Lenka Slepičková, Michaela Bartošová
}

\begin{abstract}
Motherhood - at least in Western countries - is perceived more as the result of a free choice than an inevitable destiny. Women can and simultaneously must choose if, when and how they become mothers. However, full control over reproduction is an illusion. Women have to consider many factors beyond their control - in addition to their individual desire to have a child, women must take into account the socially and culturally defined conditions of motherhood and biological limits of reproduction. Efforts to fulfil the expectations of being a good mother can lead to prolonging the period of temporary childlessness, which can result in permanent childlessness. Our research compares two groups of women experiencing a situation in which their desire to have a child was not consistent with the other conditions of motherhood. The first study is focused on women who delayed motherhood because of an absence of a partnership. The second study deals with women who suffer from infertility. The paper poses the following question: How is the norm of being a good mother defined and redefined when its fulfilment is not possible?
\end{abstract}

KEYWORDS Age norms, delayed motherhood, infertility, reproduction, transition to motherhood

\section{Úvod}

Mateřství je v dnešních západních společnostech vnímáno jako svobodná volba, nikoli nevyhnutelný ženský úděl. Ženy, v rámci svých možných životních stylů, mohou a musí rozhodovat o tom, kdy a za jakých podmínek se chtějí stát matkami, př́ípadně jestli vůbec chtějí. Úplná kontrola nad reprodukcí je však jen zdánlivá, ženy ve svém rozhodování zvažují řadu faktorů, které nemohou ovlivnit - kromě individuální touhy po dítěti do rozhodování vstupují sociálně a kulturně definované podmínky a normy mateřství a biologické limity reprodukce. Snaha o naplnění norem souvisejících s mateřstvím vede k prodlužování období dočasně chápané bezdětnosti, které může vyústit v bezdětnost celoživotní (Ireland 1993, Sobotka 2006).

V našem výzkumu využíváme narativní přístup (Wengraf 2001) a perspektivu životních drah (Elder, Johnson a Crosnoe 2004; Gubrium a Holstein 1997; Hunt 2005) ke srovnání výpovědí dvou skupin žen, které jsou, nebo byly nuceny v určité fázi svého života čelit situaci, kdy jejich touha po dítěti nebyla v souladu s jinými podmínkami mateřství. V prvním

Sociální studia. Fakulta sociálních studií Masarykovy univerzity, 2/2008. S. 35-54. ISSN 1214-813X.

1 Tato studie vznikla s podporou Ministerstva školství, mládeže a tělovýchovy - výzkumný záměr „Reprodukce a integrace společnosti“ (MSM0021622408). 
př́ípadě jde o ženy, které odkládaly mateřství kvůli absenci partnerského vztahu - podmínky, kterou definovaly jako nezbytnou, ve druhém prípadě se realizaci rodičovství postavila do cesty fyzická překážka v podobě neplodnosti. Chceme popsat, jaký vliv na sebe mají sociálně a kulturně definované podmínky a normy mateřství s fyzickými limity reprodukce, a také, jak se tento vliv projevuje $\mathrm{v}$ životních drahách žen, do jejichž rozhodnutí stát se matkou vstoupila v určité fázi jejich života překážka. Ptáme se, jaké strategie v této životní situaci zvolily, jak je legitimizují a zda a jakým způsobem přehodnocují normu správného mateřství, zejména normu věkovou. Obecně nás zajímá, jakým způsobem jsou jednotlivé fáze jejich životní dráhy konstruovány a interpretovány.

\section{„Postmoderní“ životní dráhy}

Koncept životních drah nahradil dř́ive používané pojetí životního cyklu, kterému byl vyčíán etnocentrismus a jeho špatná aplikovatelnost na společenské změny spojené s obdobím pozdní modernity (Hunt 2005). Teorie životního cyklu vycházely z normalizované, standardizované představy jednotlivých životních fází, které odpovídaly určitému věku (Erikson 1994). Koncept životních drah naproti tomu počítá s předpokladem individuálně konstruované biografie a s ní spojeného pořadí a načasování jednotlivých událostí. Pracuje se třemi dimenzemi: První, biografický čas, reprezentuje chronologii v životě jedince. Budoucí události jsou ovlivněny předchozími, události z určité sféry života se odrážejí v jiné sféře. Druhá, čas historický, popisuje vliv vnějších událostí na individuální život. Třetí, čas sociální, ukazuje vliv aktuálních sociálních a kulturních norem, specifických pro určitý věk. Jedinec konstruuje svou životní dráhu prostřednictvím určitých voleb, na které mají vliv možnosti nebo naopak překážky vyplývající z konkrétního sociálního a historického kontextu. Na podobu životních drah má vliv také interakce mezi jedinci (van Wissen a Dykstra 1999).

Jedním z důležitých pojmů v konceptu životní dráhy je tranzice. Elder (1992) ji charakterizuje jako moment, ve kterém se jedinec dostává do nových situací a s tím souvisejících rolí. Z nich vyplývají nová práva a závazky, často také nové aspekty sociální identity. Tyto přechody mezi jednotlivými fázemi životní dráhy jsou uvozovány určitými událostmi. V období rané dospělosti to jsou podle Elder (1992) vzájemně propojené události z různých oblastí života: odchod z domu rodičů, dokončení vzdělání, vstup na pracovní trh, vstup do manželství, rodičovství.

Hunt (2005) označuje současnou podobu životních drah v západní společnosti jako postmoderní nebo pozdně moderní. Životní dráhy přestávají být rigidní a nutně chronologické, pro jednotlivé fáze již neplatí fixní definice, přechodové rituály jsou volitelnými, nikoli povinnými aspekty sociálního života. Postmoderní nebo pozdně moderní společnost je charakterizována jako společnost vysoce individualistická (Giddens 1991, Beck 1994), dř́ve mocné aspekty statusu (trř́da, věk, gender) ztrácejí na významu, jedinci jsou nuceni „vytvářet, uspořádávat a skládat dohromady své biografie zcela sami“ (Beck, Giddens a Lash 1994:13).

Individualizace na jedné straně otevřela prostor pro vlastní rozhodnutí jedince a svobodu výběru, na druhou stranu přinesla nutnost internalizovat nové požadavky. Možnost být zodpovědný sám za sebe je vykoupena nutností být závislý na podmínkách, které jsou konkrétním jedincem zcela neovladatelné a nad kterými nemá žádnou moc - člověk je „povinen 
normalizovat svou vlastní existenci. Jedinci osvobozeni od tradičních omezení zjištují, že jsou řízeni pracovním trhem, a proto závislí na nabídkách školení, regulacích sociální péče a podpor, na veřejné dopravě do mateřských škol a otevírací době, studentských stipendiích a důchodových plánech“ (Beck a Beck-Gersheim 1995:7). Lidé jsou nuceni k tvorbě a uspořádání vlastního životního př́iběhu, včetně závazkủ, sítí preferencí a fází životní změny, vše v podmínkách a modelech sociálního státu.

Vzájemná provázanost jednotlivých tranzicí v životních drahách a možnost svobodně rozhodovat o pořadí těchto přechodů může vést $\mathrm{k}$ nezamýšleným důsledkům. Podle výzkumu Hagestad, Call a Vaughn (2007) může mít pozdější realizace přechodových událostí v období rané dospělosti dominový efekt. V jejich výzkumu byly životní dráhy bezdětných často charakteristické pozdějším zahájením klíčových tranzicí (samostatné bydlení, dokončení vzdělání a sňatek) a větší časovou prodlevou mezi nimi. Struktura a načasování těchto událostí byly ovlivněny ekonomickými (trh práce), strukturálními (sociální politiky) a demografickými faktory (možnosti sňatkového trhu).

\section{Místo mateřství v životní dráze ženy}

Mateřství se podobně jako jiné události v individuální biografii stává záležitostí volby, jednou z možných životních cest (Giddens 1991), zároveň se však charakteristikám ostatních fází životních drah vymyká. Beck (2004) upozorňuje na to, že v životě „pozdně moderního“ člověka je vztah mezi rodičem a dítětem posledním poutem, které nelze vzít zpět, jediným primárním vztahem, který přetrvává (v kontrastu se vztahy partnerskými) a jako takový brzdí absolutní individualizaci člověka a jeho adaptabilitu na požadavky trhu. Oakley (1980) zdůrazňuje, že mateřství je kromě všech svých sociálních charakteristik stále také událostí biologickou, podobně jako smrt nebo nemoc. Limitům západoevropské představy svobodného a individuálního rozhodování o mateřství, umocňované rozvojem asistované reprodukce (která zahrnuje jak antikoncepci, tak metody umělého oplodnění), se věnovala řada dalších autorů a autorek. Omezení s sebou nese samotné rozhodnutí nebýt matkou a zůstat bezdětnou. Mateřství je pevně spjato s ženskou identitou a volba nestát se matkou je i v době nárůstu bezdětnosti stále vnímána jako deviantní a patologická (Meyers 2001; Earle a Letherby 2007; Maher a Saugeres 2007).

Mateřství je spojováno se silnými sociálními a kulturními narativy, které určují jeho „správnou“ podobu a „rozumné“ zasazení do životní dráhy (Bailey 1999; Sevón 2005; Maher a Saugeres 2007). Rozhodování žen o mateřství má pak podobu snahy sladit obsah těchto narativů, reflexivně konstruovanou životní dráhu a limity dané fyzickým věkem. V českém prostředí normu správného mateřství popsaly Hašková a Zamykalová (2006): matkou je nutné být, mateřství je třeba plánovat a je nutné o něj ve správný čas začít usilovat, má se jednat o mateřství biologické, vzešlé z heterosexuálního vztahu a žena má o dítě několik let pečovat jako výhradní pečovatelka. Bezdětné ženy podle autorek normu nenarušují, ani nezpochybňují. Některé z nich mateřství odsouvají nebo odmítají právě proto, že mají obavu, zda by normě dostály (podobně také výzkum Maher a Saugeres 2007).

V našem výzkumu se chceme zabývat ženami, které se matkami v určité chvíli chtěly stát (a některé se i později staly). Autonomie jejich rozhodnutí a vědomí připravenosti je však narušena vlivy, které mohou ovlivnit jen málo - nemají vhodného partnera, který by 
byl ochotný s nimi založit rodinu, nebo se rodičovství do cesty postavila fyzická překážka v podobě neplodnosti.

\section{Metodologie}

Východiskem naší analýzy je sociálně-konstruktivistický př́stup (Berger a Luckmann 1999), zajímá nás zejména, jak jsou jednotlivé fáze životní dráhy konstruovány a interpretovány, především ve vztahu k mateřství. Vycházíme z předpokladu, že význam životních fází je imaginativně budován na individuální úrovni (LaRossa a Sinha 2006) a zároveň konsensuálně utvářen na základě sdíleného porozumění o věkových a přechodových rolích (Holstein a Gubrium 2007).

Použitým výzkumným nástrojem jsou kvalitativní rozhovory, kombinující narativní přístup (zejména $\mathrm{v}$ první části rozhovoru) s předem připraveným „scénářem“, sestaveným z několika tematických částí. Tato témata nebyla konverzačním partnerkám striktně vnucována, ale využívána k prohloubení hlavního výzkumného tématu v př́padě, že aktérka dokončila odpověd' a čekala na otázku. Narativní př́stup nepouživáme k výzkumu celé biografie, ale pro zkoumání konkrétního období životní dráhy žen (Wengraf 2001). Důraz klademe na samostatné výpovědi aktérek o vlastních zkušenostech a na to, jak je propojují se širším sociálním kontextem. Tento způsob zkoumání zdůrazňuje interpretativní úlohu aktérek jako tvůrkyní významů a umožňuje zkoumat, jak jsou jejich osobní prŕiběhy propleteny se sociálními a kulturním narativy a jak jsou tyto narativy používány k porozumění určitým životním zkušenostem (Sevón 2005, Miller 2005).

Během první části rozhovoru jsme konverzační partnerky požádaly, aby vyprávěly odkdy, jakým způsobem a v souvislosti s jakými událostmi přemýšlely o mateřství až do doby, kdy dítě měly nebo byly konfrontovány s neplodností; jak jejich život po tuto dobu probíhal. Vybídly jsme je k co nejúplnější samostatné výpovědi. Následující otázky už uvozovaly konkrétní výzkumné téma, to znamená okolnosti jejich bezdětnosti nebo mateřství. Konverzační partnerky jsme požádaly o rozvedení témat, která zmínily dříve, nebo o jejich doplnění, případně jsme nabídly téma nové. S každou participantkou výzkumu byl proveden jeden rozhovor, který trval jednu až dvě hodiny. Rozhovory byly nahrávány na diktafon, doslovně přepsány (s vynecháním všech potenciálně identifikujících charakteristik) a analyzovány.

Analýza sledovala induktivní logiku, typickou pro kvalitativní př́stup. Rozhovory byly analyzovány s pomocí programu Atlas.ti. Při analýze rozhovorů jsme se soustředily na výpovědi žen o překážkách souvisejících s přechodem $\mathrm{k}$ mateřství a reakci na ně a identifikovaly jsme hlavní témata, se kterými konverzační partnerky tuto situaci spojovaly. Jednotlivá témata a tematické kategorie byly podrobně definovány, seskupovány a konfrontovány nejprve odděleně v obou výzkumech a následně analyzovány jako celek. Výsledkem analýzy je podrobná deskripce specifických bariér přechodu k mateřství v př́ípadě dvou skupin žen.

\section{Charakteristiky účastnic výzkumu}

Analyzované rozhovory pocházejí ze dvou samostatných výzkumů: „Mateřství po třicítce“ a „Nedobrovolná bezdětnost.“ Oba výzkumy jsou součástí větších výzkumných 
záměrů a vzhledem $\mathrm{k}$ našim výzkumným otázkám a zaměření tohoto článku byly pro analýzu vybrány jenom ženy splňující určité charakteristiky. Z prvního výzkumu to byly pouze ženy, kterým do rozhodnutí o mateřství vstoupila překážka $\mathrm{v}$ podobě absence partnera a potenciálního otce dítěte. Tyto ženy považují své mateřství za odkládané a první dítě porodily po dosažení třiceti let. Ze druhého výzkumu byly $\mathrm{k}$ analýze vybrány rozhovory s ženami, kterých se týká (nebo týkala) diagnóza primární neplodnosti (tzn. problémy s početím prvního dítěte), bez ohledu na to, zda je fyzická pŕícina odhalena nebo u kterého z partnerů byla nalezena. Klíčovým kritériem zařazení do výzkumu byla skutečnost, že kvůli problémům s neplodností navštěvují nebo navštívily specializovaného lékaře.

Výzkumné rozhovory probíhaly od dubna do prosince roku 2007. Konverzační partnerky byly kontaktovány $\mathrm{v}$ rámci sociálních sítí výzkumnic a následně technikou sněhové koule. Ženy z výzkumu „Nedobrovolná bezdětnost“ byly vyhledávány také přes internetové diskusní servery zaměřené na mateřství a neplodnost.

Tyto dvě rozdílné skupiny žen spojuje skutečnost, že přestože byly k mateřství rozhodnuty a připraveny, nemohly se matkami stát. $\mathrm{V}$ prvním př́padě, protože neměly partnera, který pro ně byl - nejen v biologickém smyslu - nezbytnou podmínkou mateřství, ve druhém př́ípadě jim v početí dítěte bránila fyzická neplodnost - vlastní nebo na straně partnera. Obě tyto skupiny tak byly nuceny přehodnocovat své původní představy o mateřství a snažit se překonat překážky jeho uskutečnění. Jejich výpovědi jsou nepochybně ovlivněny situací, ve které byly v době uskutečnění rozhovoru. Zatímco aktérky výzkumu „Mateřství po třicítce“ se již matkami staly, ženy z výzkumu „Nedobrovolná bezdětnost“ se ocitaly v různých fázích cesty za mateřstvím - dvě konverzační partnerky počaly dítě díky umělému oplodnění a vracejí se k němu při snaze o početí druhého dítěte, jedna byla matkou adoptivního syna a jedna těhotná. Ostatní konverzační partnerky byly bezdětné a procházely léčbou neplodnosti, dvě z nich čekaly na přijetí adoptovaného dítěte. Další charakteristiky konverzačních partnerek z obou výzkumů obsahuje Tabulka 1 .

\section{Tabulka 1}

\begin{tabular}{|c|c|c|c|}
\hline Jméno & Věk* & Vzdělání & Název výzkumu \\
\hline Sylvie & $33(31)$ & VŠ & Mateřství po třicítce \\
\hline Markéta & $43(38)$ & VŠ & Mateřství po třicítce \\
\hline Diana & $37(35)$ & VŠ & Mateřství po třicítce \\
\hline Anna & $37(34)$ & SŠ & Mateřství po třicítce \\
\hline Dagmar & $36(34)$ & VŠ & Mateřství po třicítce \\
\hline Evelína & $34(34)$ & VŠ & Mateřství po tř̌icítce \\
\hline Blanka & $33(32)$ & SS̆ & Mateřství po třicítce \\
\hline Jindřiška & $32(31)$ & VŠ & Mateřství po třicítce \\
\hline Sandra & $34(34)$ & VYUČ & Mateřství po třicítce \\
\hline Martina & $31(31)$ & V̌s & Mateřství po třicítce \\
\hline Karla & $34(33)$ & $\mathrm{SS}$ & Mateřství po třicítce \\
\hline Kamila & $35(33)$ & VŠ & Mateřství po třicítce \\
\hline
\end{tabular}




\begin{tabular}{|c|c|c|c|}
\hline Jméno & Věk* & Vzdělání & Název výzkumu \\
\hline Hanka & 30 & S Šs & Nedobrovolná bezdětnost \\
\hline Romana & 41 & VŠ & Nedobrovolná bezdětnost \\
\hline Mirka & 34 & VŠ & Nedobrovolná bezdětnost \\
\hline Ivana & 30 & VŠ & Nedobrovolná bezdětnost \\
\hline Jarka & 31 & VYUČ & Nedobrovolná bezdětnost \\
\hline Barbora & 34 & VŠ & Nedobrovolná bezdětnost \\
\hline Dana & 35 & $\mathrm{SS}$ & Nedobrovolná bezdětnost \\
\hline Vendula & 30 & SŠ & Nedobrovolná bezdětnost \\
\hline Linda & 33 & VŠ & Nedobrovolná bezdětnost \\
\hline Marie & 38 & SŠ & Nedobrovolná bezdětnost \\
\hline Kateřina & 29 & VŠ & Nedobrovolná bezdětnost \\
\hline Dita & 28 & SŠ & Nedobrovolná bezdětnost \\
\hline Pavla & 33 & SŠ & Nedobrovolná bezdětnost \\
\hline Lada & 30 & SŠ & Nedobrovolná bezdětnost \\
\hline Jana & 32 & VŠ & Nedobrovolná bezdětnost \\
\hline
\end{tabular}

* Věk ženy v době rozhovoru (v závorce je uveden věk při narození prvního dítěte)

V analýze se zaměřujeme na tu fázi života žen, která mateřství předcházela nebo předchází. Jsme si vědomy toho, že retrospektivní pohled žen-matek je určitým způsobem zkreslující: vyprávění aktérů není reflexí toho, co si pamatují, ale toho, jak svoji minulost aktuálně konstruují. Zpětná rekonstrukce událostí a minulých zkušeností je ovlivněna situací, ve které se žena právě nachází (Sandelowski, Holditch-Davis a Harris 1990). Odlišný životní kontext konverzačních partnerek je při analýze brán v úvahu a v maximální možné míře reflektován.

Výsledky výzkumu mohou ovlivnit i jiné typy zkreslení, které vyplývají především ze způsobu výběru zkoumaného vzorku žen. V něm jsou více než v normální populaci přítomny ženy s vyšším vzděláním, jejichž vstup do zkoumaných životních fází je posunut. Jejich převaha ve vzorku je dána možnostmi výzkumnic a jejich sociálních sítí a menší ochotou žen s nižším vzděláním k účasti na těchto typech výzkumů. Kvalitativní výzkum, jehož perspektivu využíváme, však neaspiruje na vytvoření reprezentativního vzorku zkoumané populace, jeho cílem je vysvětlení nebo popis určitého fenoménu či vytvoření nové teorie vhodné k dalšímu zkoumání. Zobecnění, o které usiluje kvalitativní výzkum, je analytické, nevztahuje se k populaci, ale k teorii (Hendl 1997).

\section{Průběh života do rozhodnutí o mateřství}

Časování mateřství do nejvhodnějšího období v individuální životní dráze je popisováno jako jeden z moderních rysů rodičovství i součást normy správného mateřství (Hašková a Zamykalová 2006, Sevón 2005, Bailey 1999). Rodičovství je nutné aktivně plánovat období, kdy je mu bráněno pomocí antikoncepce (protože nesmí přijít př́liš brzy), má být vystřídáno obdobím usilování o něj (protože by mohlo být prŕiliš pozdě). Vhodná doba pro mateřství je pak výsledkem interakce tří faktorů: 1. kulturních a sociálních norem týkajících 
se normálního a rozumného průběhu života ženy (Sevón 2005, Bailey 1999) - mateřství je jednou z událostí, u které se předpokládá, že proběhne v konkrétní fázi života a po naplnění konkrétních podmínek, jako je např́klad stabilní partnerský vztah, materiální zabezpečení, dokončené vzdělání atd. (Earle a Letherby 2007); 2. individuálních plánů a aspirací - podle Mareše (2002) jde především o poměřování touhy po mateřství s touhou dělat jiné věci; 3. věkových omezení ženského reprodukčního zdraví.

Sled životních událostí, které předcházely reálným úvahám o mateřství, ženy z obou výzkumů („Mateřství po třicítce“ a „Nedobrovolná bezdětnost“) nijak nezpochybňují a nezmiňují se o tom, že by některá $\mathrm{z}$ fází byla nechtěná nebo následovala $\mathrm{v}$ jiném pořadí, než jak si představovaly. U většiny z nich zahrnovalo toto životní období dokončení studia a nabývání pracovních zkušeností. Pracovní aktivita byla konverzačními partnerkami popisována bud' jako kariéra ve smyslu upevnění nebo získání výhodné pozice na trhu práce v souvislosti s vlastní seberealizací, nebo jako nutný zdroj zajištění sebe sama i budoucí rodiny. Často však tato fáze následuje po dokončení studia, bez zvažování varianty přímého odchodu na mateřskou nebo potřeby tuto volbu nějak reflektovat. S tím souvisí také další předpoklad mateřství, kterým je zajištění vlastního bydlení, které ovšem není vnímáno pouze ve smyslu nezbytného fyzického zázemí, ale také jako utvrzení vlastní samostatnosti a nezávislosti. Motivace k práci jako zdroji finančního a materiálního zabezpečení nutného pro založení rodiny se proto prolíná s čistě individualizační tendencí prožít jinou, nezávislostí charakterizovanou životní zkušenost, než je mateřství:

... a potom jsem si chtěla sama pořídit ten byt, hodně jsem ho chtěla, já nevím proč, ale chtěla jsem si ho pořídit sama, bez partnera. Vím, že je to blbost, ted'ka zpětně když se na to dívám, ale kdysi jsem na tom strašně lpěla a obětovala jsem tomu cokoliv. (Diana). ${ }^{2}$

Finanční nezávislost umožňuje různé způsoby seberealizace, at' už prožívané společně s partnerem či manželem, nebo bez něj. Kromě pracovní kariéry může jít o cestování nebo pěstování náročnějších koníčků, které jsou považovány za těžko slučitelné s budoucím rodinným životem.

U některých žen trvalo období předcházející snahám o mateřství relativně krátce (Jitka byla na mateřství připravena po svatbě $v$ jednadvaceti letech, Kateřina nebo Dita se chtěly stát matkami ve věku kolem pětadvaceti let), jiné ženy naopak spadají do kategorie tzv. „late bloomers“, tak jak je popsala Ireland (1993). ${ }^{3}$ Období předcházející „usazení se“ a založení rodiny prodlužovaly, at’ už proto, že využily otevřených možností krátce po roce 1989 jako Romana, která odcestovala na dlouhou dobu do Austrálie, nebo Marie, která se se svým

2 Marcel Tomášek (2006b) upozornil na skutečnost, že pro mladé, dosud nesezdané a ekonomicky nezávislé jedince, označované termínem singles, může být samostatné bydlení potvrzením vlastní ekonomické samostatnosti, ale také možností mít intimní prostor pouze sám/sama pro sebe. Tuto tendenci dává do souvislosti s tzv. individualizačním habitem, který se postupně prosazuje po roce 1989 jako důsledek hlubších změn v oblasti genderových a rodinných vztahů.

3 Jako „late bloomers“ označuje Ireland (1993) ženy, které mateřství delší dobu odkládaly, až dítě nakonec nestihly mít. Je pro ně typické dlouhé období adolescence, politický aktivismus, cestování, střídání různých životních stylů. 
manželem pustila do „,hektického“ podnikání. Pavla, která po dokončení stř̌ední školy odjela jako au-pair do zahraničí, reflektuje mimo jiné i své vyloučení ze skupiny vrstevnic:

Já jsem totiž v tom věku, kdy moje spolužačky se povdávaly a těhotněly, byla ve Švýcarsku. Takový ten věk, jak to bylo dřív, jednadvacet, dvacet dva, dvacet tři. Já jsem se vrátila, když mi bylo nějakých pětadvacet, kamarádky povdávané, kočárky, a já jsem byla ráda, že jsem svobodná. A ony už v tu dobu po nějakých třech, čtyřech letech manželství zjistily, že to asi není to, co chtěly tak mladý, a tak mi záviděly. A ony ještě jak byly uštvaný... to mě vůbec nebralo. Říkám ne, nemusím. Dneska jsou taky všechny rozvedený. (Pavla)

Do této kategorie spadají i některé ženy z výzkumu „Mateřství po třicítce“. Část z nich začala o mateřství uvažovat až v pozdějším věku, čemuž mohl předcházet i posun v časování předešlých životních fází (např. odchod od rodičů u nich probíhal později než u stejně starých vrstevnic). Tato etapa je pro ně typická nejen stř́idáním životních stylů, ale také např́iklad existencí tzv. alternativních vztahů, které jsou charakteristické chybějící perspektivou založení rodiny (Tomášek 2006a).

Nejdůležitější podmínkou mateřství, na jejíž splnění je třeba - je-li to nutné - i dlouhou dobu čekat, byl pro většinu žen z obou výzkumů stabilní partnerský vztah a společné rozhodnutí o rodičovství. Nalezení „toho správného muže“ (slovy několika konverzačních partnerek) bylo v tomto období klíčové. Neuspokojivé nebo nerealizované partnerské vztahy fungovaly u obou skupin žen jako hlavní brzda snah o mateřství. Před tím, než poznaly svého aktuálního partnera, prošly ženy často řadou vztahů, které z různých důvodů k rodičovství nevedly - někdy to přímo vyplývalo z jejich podstaty (ženatí partneři). Tyto vztahy ženy ve chvíli, kdy se pro ně touha založit rodinu ukázala jako přednější než aktuální partner, ukončily. Pokud se neperspektivní partnerské vztahy střetly s možností zajímavé kariéry, úvahy o dítěti byly na čas odsunuty:

Vždycky jsem si myslela, že budu mít děti a potom, když jsem začala budovat tu kariéru, být samostatná, byla jsem sama a stačilo mi to, občas jsem měla př́itele, ale nikoho na život. [...] Až potom jsem začala hledat toho pravého, i když jsem věděla, že čím jsem starší, tím jsem náročnější a bude to těžší. (Barbora)

Vytíženost nebo zaměřenost na práci v tomto období je možné v mnoha případech chápat spíše jako zdroj využití volného času, který se ženě otevírá v př́ípadě, kdy aktuálně žije sama, nebo v (zatím) bezdětném vztahu, než jako upřednostňování kariéry před rodinným životem.

Kromě toho, že pro mateřství je třeba připravit odpovídající zázemí ve smyslu ekonomickém (vzdělání, pracovní perspektiva), fyzickém (bydlení), psychickém (vyrovnanost sama) a partnerském (vyhovující partnerský vztah), je třeba k němu i dozrát, dospět, opravdu po něm toužit. Tuto touhu ženy často popisují pomocí metafory „,biologických hodin“, jako iracionálního, vnitřního popudu k mateřství.

Vědomí zralosti, dospělosti nebo připravenosti na dítě je často provázeno přehodnocením minulých postojů a názorů na mateřství, které mohou souviset se zkušenostmi z dětství a primární rodiny (Kammeyer a Ginn 1986; Ireland 1993; Bartošová 2007). Konverzační partnerka Dagmar také zmínila životní stádium, ve kterém se dívka mění v ženu v tom smyslu, 
že se smiřuje s událostmi spojenými s mateřstvím: porod, který dř́ve vnímala jako nepředstavitelnou zkušenost provázenou studem z vlastního těla, přijala s postupujícím věkem jako přirozenou součást mateřství.

Období předcházející mateřství naplnily konverzační partnerky dvěma typy aktivit: těmi, které k mateřství směřují nebo mu připravují podmínky, a činnostmi, které slouží seberealizaci v různých oblastech života, touze po osamostatnění se a po jiné životní zkušenosti, než jaká je očekávána od mateřství. Některé ze zmiňovaných aktivit mají oba významy, ve výsledku však můžou působit kontraproduktivně, jako překážka hledání vhodného partnera a budování rodiny.

\section{Věkové normy mateřství}

Do sledu událostí, které jsou vnímány jako volně plynoucí a přirozeně navazující a které jsou u jednotlivých žen různě dlouhé, vstupuje jiná časová rovina: fyzický věk, jehož vliv na reprodukční zdraví ženy je konverzačními partnerkami popisován jako nezpochybnitelný a neúprosný, a to častěji, pokud se otěhotnění ukázalo jako problematické, at’ už kvưli jejich vlastní nebo partnerově diagnóze. Kromě obecné schopnosti otěhotnět a dítě donosit zvažují tyto ženy i další vlivy postupujícího věku: psychický (starší matky jsou úzkostlivější), tělesný (starší matky jsou unavenější, nevypadají hezky) i morální (pořídit si dítě v pozdním věku může znamenat připravit jej o zdravou a aktivní matku). Konfrontace s mateřstvím ve vyšším věku u nich má podobu stanovování si hranic pro pokusy o umělé oplodnění.

Ženy z výzkumu „Mateřství po třicítce“ si v době před narozením dítěte byly sice vědomy rizik souvisejícím $\mathrm{s}$ věkem, ale vzhledem ke své touze po dítěti si je nechtěly př́íliš připouštět. Věk, ve kterém se nakonec staly matkami, nehodnotily jako problematický. Kromě únavy zmiňovaly jen pozitivní dopady pozděšš́ho vstupu do mateřství, jakými jsou dospělost, vyrovnanost, dostatečná předchozí seberealizace.

Úvahy o věku jsou v průběhu rozhodování o mateřství pro mnohé ženy klíčové - je popisován jako stresující faktor (,,člověka tlači ten věk" - Mirka), i jako jeden z motivů pro jejich jednání. První věkovou hranici, kterou ženy zmiňují, je 25 let. Jde o období přehodnocování postojů a názorů na mateřství, ženy poprvé vážně uvažují o své roli matky nebo již vnímají tikot biologických hodin. Zároveň je však tento věk hodnocen jako nedostatečný ke vstupu do mateřství, vzhledem k finanční a materiální nepřipravenosti (nedokončení studia, nezajištěné bydlení), ale také jako doba, kdy nejsou naplněny ostatní životní zkušenosti, které se ženě v tomto věku nabízí (cestování, koníčky, zkušenost ze zaměstnání). Jako optimální věk pro mateřství označují ženy obvykle období mezi 25-30 lety. V období 27-29 let věku si již více uvědomují blížící se třicítku. Některé se snaží uspořádat si život tak, aby co nejrychleji mohly založit rodinu (,,já jsem se vrátila ze zahraničí ve dvaceti sedmi, takže to byly tři roky intenzivního hledání partnera " - Anna), pořád jde však většinou o věk, kdy je podle konverzačních partnerek ,,ještě čas “ (Karolína). U jedné ženy - vysokoškolačky došlo $\mathrm{v}$ tomto období $\mathrm{v}$ jejím životě $\mathrm{k}$ zásadním změnám, které souvisely s proměnou životního stylu (dokončuje školu, většinu času tráví v zaměstnání, přátelé-vrstevníci se vracejí do rodných měst, zakládají rodiny). Tento věk hodnotí jako větší zlom než blížící se třicítku (vliv událostí je v tomto př́padě významnější než normativní hranice věku). Obecně lze říct, že být 
bezdětnou v této době je sice vnímáno jako běžné, alarmující však je, pokud je žena v této době zároveň sama, bez stálého partnera, a tedy i bez reálné perspektivy založení rodiny v budoucnosti.

Nejmocnější věkovou hranicí je třicítka, která funguje jako referenční bod i významný zlom v postojích i strategiích většiny žen. Třicítka vystupuje z rozhovorů žen jako magická hranice, jako věk, kdy se relativně bezstarostné období osobního zrání, pestrých volnočasových aktivit a hypotetických úvah o mateřství, př́padně období, kdy je i nedobrovolná bezdětnost dobře prožívaná a zvládnutelná, radikálně mění. Po třicítce už slovy konverzačních partnerek „,není na co čekat" (Dita), ,je nejvyšši čas “ (Marie, Dana, Vendula) o mateřství reálně uvažovat, př́ípadně podnikat kroky $\mathrm{k}$ jeho realizaci. Pokud třicítka zasáhne ženu již v období neúspěšných snah o otěhotnění, je popisována jako zlomový bod, od kterého se prožívaný stres zvyšuje spolu se sílící touhou po mateřství. Být ve dvaceti devíti letech bezdětná je v pořádku, ale ,jak se ta třicitka objeví, tak je to zdrcujici“" (Hanka). I mladší ženy popisovaly strach z toho, že zůstanou bezdětné, když ,udeři třicet" (Dita). Ve třiceti letech se člověk dostává do životní fáze, jejímž správným naplněním je zakládání rodiny. V této době ženy pocit'ují touhu po usazení se, zklidnění, změně životního stylu - cítí, že přišla vhodná doba na rodinný život. Prodlužování období seberealizace už nepřináší uspokojení.

No, že jsem si už naplnila ty moje představy, že jsem byla ve světě a tu práci jsem měla celkem dobrou, ten byt jsem měla a pak už mi začalo něco chybět, já jsem se neměla za čím hnát, takže tam bylo nějaké prázdný místo, v životě. (Diana)

Dalším zlomovým bodem je 35, př́ípadně 38 let, tento věk je vnímán jako jedna z maximálních hranic mateřství. První limit je také limitem, od něž v České republice začíná zvýšená lékařská péče $\mathrm{v}$ těhotenství $\mathrm{v}$ souvislosti s věkem matky, zároveň se uvádí jako věk, od nějž výrazně stoupá riziko vývojových vad dítěte, například Downova syndromu. Ženy svou maximální hranici pro vstup do mateřství často dávají do souvislosti s těmito medicínskými informacemi. Pro jiné ženy je naopak 35 let přijatelný věk pro narození prvního dítěte, především proto, že se této hranici samy blíží. Ve výzkumu žen, které měly své dítě až po třicítce, je obecně mezní hranice posunuta do pozdějšího věku.

V reflexi vlastního věku se promítají tř̌i definice: subjektivní, ,jak se člověk cítí,“ která je konfrontována s definicí lékařskou, se kterou může a nemusí být v rozporu. Zatímco některé konverzační partnerky vliv vlastního věku bagatelizují s odkazem na to, že se cítí dobře, Romana zdůrazňuje lékařské vymezení, které své vlastní definici nadřazuje.

Já se cítím mladá a možná navenek tak vypadám, ale realita je taková, že je mi čtyřicet jedna let a tělo je čtyřiceti jednaletý a tam zákonitě a neúprosně genetika je jaká je a ten čas se nedá zastavit. (Romana)

Lékařská definice je kromě subjektivních pocitů relativizována také s odkazem na pozitivní prríklady zralého mateřství (a $\mathrm{v}$ kontrastu s tím na velmi mladé ženy, které se léčí pro neplodnost) a na společenské změny, jež posunují věk při zakládání rodiny. Věkovou hranici mateřství mohou posunout také pokroky lékařské vědy, o kterých se dozvídáme z médií (popularizované př́klady mateřství po šedesátce), které jsou , děsivé “ a zároveň „úžasné “ (jak to vyjádřila konverzační partnerka Romana). 
Lékařským určením vhodného věku pro mateřství jsou mnohem více ovlivněny ženy ze skupiny nedobrovolně bezdětných. Souvisí to pravděpodobně se skutečností, že jsou s lékařskou profesí více $\mathrm{v}$ kontaktu a věkové limity spjaté $\mathrm{s}$ matersstvím ${ }^{4}$ pro ně mají mnohem konkrétnější význam. Tlak zvnějšku daných věkových hranic konfrontují s jinými definicemi: at' už se subjektivním hodnocením vlastní kondice, nebo se společenskými změnami (viditelnými skrze pozdní mateřství celebrit i pokroky vědy), př́padně s konkrétními příklady z vlastního okolí.

\section{Adaptace na situaci: redefinice individuálních představ a společenských norem}

Zlomovým obdobím $\mathrm{v}$ životě konverzačních partnerek, které je také středem zájmu našeho zkoumání, je situace, kdy byly rozhodnuté dítě mít, ale neměly vhodného partnera, nebo zjistily, že početí komplikuje neplodnost. V následující kapitole se věnujeme oběma skupinám zvlášt' a všímáme si toho, jak jsou ženy konfrontovány se svou touhou po dítěti a realitou, která ji nedovoluje naplnit.

\section{Partner jako hlavní podmínka i bariéra mateřství}

Aktérky výzkumu „Mateřství po třicítce“ pokládaly za nejvýznamnější bariéru mateřství, která je nadřazena ostatním (jako například nedostatku financí nebo materiální nejistotě), neprítomnost perspektivního a stálého partnera. Představa o správném mateřství je $\mathrm{v}$ jejich výpovědích neoddělitelně spojena s představou správného partnerství. Přehodnocování idejí o mateřství bylo proto zřetelné zejména tehdy, pokud ženy musely odstupovat od takového pojetí partnerského vztahu, jaký si původně přály nebo i v souvislosti s mateřstvím představovaly. Několik konverzačních partnerek po neúspěšných vztazích nebo možnosti nalézt partnera obvyklou cestou zvolilo jiné způsoby hledání:

Pak jsem to vzala i přes ty seznamovací agentury, už jsem to vzala natvrdo, a to je teda taky zoufalý, protože tam jsou náplavy, dneska to je asi vůbec strašidelný... (Anna)

Skutečnost, že je to pro citovanou konverzační partnerku mezní řešení situace, je patrná nejen z předešlého úryvku, ale i z jejího přiznání, že o způsobu seznámení s jejím manželem, kterého nakonec poznala díky seznamovací agentuře, téměr̆ nikdo neví.

I kritéria výběru partnera se mění s přibývajícím věkem. Ve chvíli, kdy na ženy doléhá zvyšující se věk a mateřská touha, se často zdá být hlavním měřítkem volby partnera právě jeho ochota a rozhodnost $\mathrm{k}$ založení rodiny. Jedna z žen na hypotetickou otázku, zda by si svého manžela vybrala i před deseti lety - ve 25 letech, odpověděla:

Určitě ne, myslím, že ne. To jsme byli úplně jinak naladěni. Já myslím, že velkou roli hrálo to, že jsme oba dva někoho hledali. Takže jsme třeba zavřeli oči nad nějakými nedostatky, které jsou z hlediska společného soužití ne až tak moc podstatné. (Sylvie)

4 Jedná se o hranice definované procentuální úspěšností umělého oplodnění nebo jeho úhrady zdravotními pojišt'ovnami, či výskytem vrozených vývojových vad. 
Dotazované ženy nemluví doslova o kompromisu nebo slevení za svých požadavků, nicméně z výpovědí mnohých z nich je zřejmé, že úvahy o partnerství se mění pod vlivem hrozící bezdětnosti nebo samoty. Jedním z aspektů vztahu, který se s věkem neodvratně vytrácí, je podle mnoha aktérek výzkumu zamilovanost nebo dlouhodobější prožívání romantického vztahu (schůzek, chození atp.):

Už od té doby, co jsem dala ten inzerát, tak to bylo velmi racionální, a po třicítce ti hlavně nic jiného nezbývá, romantika už je pryč, člověk do toho musí vložit úplně všechno. (Dana)

Konverzační partnerka Sandra sice zdůrazňovala spolehlivost, pravdomluvnost a zaměření na rodinu jako hlavní vlastnosti partnera a potažmo otce dítěte, rodinné tendence jejího manžela se paradoxně nezdály být z její výpovědi př́liš silné. Svého, o šest let mladšího partnera, si vybrala především z důvodu podobné touhy po usazení a rodině jako měla ona. Během rozhovoru však opakovaně vyslovila své obavy z toho, jestli vůbec bude schopný se o dítě postarat a stěžovala si na jeho závislost na matce, na jeho neschopnost jakkoliv finančně spravovat a vést domácnost. Zdá se, že vědomí jistoty o partnerovi jako dobrém otci může být nahrazeno jen jeho ochotou dítě vůbec mít.

Dagmar naopak navázala se svým budoucím mužem vážný vztah „,pouze“ kvůli hlubšímu partnerskému porozumění, a to i navzdory jeho pochybnostem o realizaci vlastního otcovství. Pokud by se pro dítě nerozhodl, byla připravená jej opustit a hledat jiného partnera. Otěhotněla nakonec neplánovaně - zůstala by i svobodnou matkou, pokud by se s ní partner o dítě nechtěl starat společně. Pořídit si dítě i bez stálého partnera je jednou ze zvažovaných variant:

...a když uhodila třicítka, tak jsem si říkala, že klidně budu i svobodnou matkou, ne hned, nebylo to tak, že bych na to myslela každý den... (Dagmar)

Dagmar byla také jediná žena, která o této alternativě nejen přemýšlela, ale vytvářela si také finanční rezervu pro případ, že by se o dítě skutečně musela starat sama. Pro jiné ženy je tento způsob, jak si pořídit dítě, naopak nepřijatelný - úplná rodina je pro realizaci mateřství nezbytná.

Těchto různých typů kompromisů nebo odstoupení od původních představ si jsou ženy v tomto věku vědomy jako nutného přizpůsobení se daným okolnostem. Někdy tento tlak odmítnou a rezignují na partnerství a mateřství za každou cenu:

Pak jsem to fakt zabalila, říkala jsem si, no dobře, není takový člověk kolem mě, tak to zabalím a postarám se o sebe... to vím, že jsme si tehdy s babičkou poplakaly. ̌̌íkala jsem, babi, nezlob se, ale jen kvůli tomu, abych měla chlapa a nějaké děcko a byli jsme všichni nešt’astní, tak kvůli tomu se já vdávat nebudu. (Markéta)

Pokud ženy nemají možnost založit rodinu, hledají jiné činnosti jako dočasnou náhradu mateřství nebo vyplnění volného času. Nejčastěji je to zaměstnání, ve kterém tráví většinu svého času, což paradoxně vede k nedostatku příležitostí se s někým seznámit. Touha po usazení se a s tím související ukončení předešlého životního stylu (cestování, setkávání s přáteli, poznávání nových lidí) u některých žen podobně kontrastovalo s předpokladem nutnosti nějakého muže vůbec potkat, tzn. chodit do společnosti, udržovat vztahy, seznamovat se s novými lidmi: 
... to pro mě bylo hrozně těžké, protože jsem se jakoby trochu usazovala... no a nehledala jsem vlastně nic, nevyhledávala jsem další přátele. A najednou mi přišlo, že mám znova jít do puberty, cítila jsem se hrozně dotčená... (Evelína)

Prodlužování dočasně vnímané bezdětnosti vede $\mathrm{k}$ nesouladu mezi tím, co by žena chtěla dělat a kroky, které musí podniknout k tomu, aby toho dosáhla. Jde o neustálé přehodnocování původních představ o životě, ale také o jeho průběhu tak, jak si ho žena představovala, nebo jaký by ho chtěla mít. Životní fáze, které měly následovat jedna za druhou, se často znovu vrací, už ne jako důsledek chtěného vývoje, ale spíše nutná náhrada za nenaplňovanou fázi mateřství. Návrat k životnímu stylu, typickému pro předchozí etapy (cestování, nebo společenský život) může k nalezení stálého partnera a budoucího otce dítěte vést, jiné činnosti (koncentrace na pracovní sféru) naopak mohou tento, přestože chtěný, přechod blokovat.

Obtížnost situace, do které se konverzační partnerky dostávají, je zřejmá i z dalších způsobů jejich chování. Těmi může být např́iklad časté stř̌́dání partnerů, opakovaná zklamání, období rezignace a opětovného snažení se. Alternativními způsoby mohou být také návštěvy astrologů, léčitelů nebo i psychologických kurzů, ve kterých se žena snaží odhalit, co dělá špatně nebo jak má jednat jinak.

Zpětně ženy hodnotí svůj neúspěch v tomto období spíše jako vlastní vinu, neschopnost nebo nedospělost, než jako vliv vnějších faktorů. Nevyčítají však samy sobě, že o dítěti nepřemýšlely dř́iv nebo propásly př́hodnější dobu. Za problém považují nedostatek vhodných partnerů, ale i vlastní neschopnost vytrvat $\mathrm{v}$ partnerských vztazích nebo si vybírat správné muže.

\section{Biologické překážky mateřství}

Situace žen z výzkumu „Nedobrovolná bezdětnost“ byla odlišná: byly rozhodnuty pro mateřství se stávajícím partnerem, ale početí dítěte se ukázalo problematické kvưli fyzickým překážkám - bud' na jejich straně (ve třech případech), nebo na straně partnera (v jednom případě), nebo v důsledku zhoršené plodnosti u obou (v šesti př́padech). Tři konverzační partnerky prríčinu neúspěchů přirozeného početí a asistované reprodukce neznaly.

Všechny konverzační partnerky byly velmi aktivní ve snaze dosáhnout početí. Jejich hlavním motorem byla silná touha po dítěti, vědomí tlaku vlastního věku a strach z bezdětnosti, spojované s osamělým stáŕím a s marnými pokusy zaplnit život jinak než rodičovstvím. Tyto „náhradní“ činnosti, jako jsou nejrůznější koníčky, charitativní aktivity, cestování nebo kariéra, jsou však označovány za ,znouzectnost“ (Linda) nebo za „,snahu zaplácnout díru $v$ životě “ (Jana), který by si žena př́la $\mathrm{v}$ této životní fázi naplnit jinak.

Vliv na rozhodnutí zahájit léčbu směřující $\mathrm{k}$ početí měli i vrstevníci dotazovaných žen. Mirce přijde paradoxní, jak moc je ve společnosti zdůrazňována izolace žen na mateřské dovolené - sama se cítí být izolovaná spíše tím, že dítě, coby „,vstupenku“ do party svých prátel, kteří své aktivity už organizují výhradně s ohledem na své potomky, nemá. Své pocity izolace mezi přáteli popsala i Jana:

My jsme přijeli někam na návštěvu a tam byly rodiny s dětmi [...] a mně tam bylo strašně smutno a já jsem zjistila, že s těma známýma, dlouholetýma, se už nechci stýkat [...]. Záviděla jsem a říkala 
jsem si, to není možné, všichni mají děti, mají si o čem povídat a my tam přijedeme a oni se mě pak třeba zeptají, tak co kočky, protože my máme dvě kočky. [...] Oni ten život opravdu žili někde jinde, jezdili s dětmi společně na dovolené, různě se setkávali a já jsem tam byla opravdu jako páté kolo u vozu, byla jsem vyčleněná z toho kolektivu, z toho běžného života, který lidi žijí. (Jana)

Ženy se snažily průběh léčby maximálně kontrolovat a přizpůsobovat svým subjektivním pocitům ohledně správného času k některým procedurám, nebo svému hodnocení schopností lékaře či pracoviště, jež si pro léčbu neplodnosti vybraly. Často hledaly pomoc nebo radu u alternativních lékařů a léčitelů, ale i astrologů a kartářek, kvůli psychickým problémům spojeným s pocity méněcennosti navštěvovaly také psychology. Kariéra a pracovní plány se dostávají do pozadí, všechny aktivity se soustřed'ují na snahu počít a je těžké je s intenzivním pracovním životem sladit, at' už časově, nebo psychicky.

$\mathrm{V}$ době, kdy je dř́ve samozřejmý předpoklad úspěšného početí dítěte radikálně zpochybněn, byly aktérky výzkumu nuceny intenzivně přemýšlet nad tím, co všechno pro ně mateřství znamená a co jsou pro jeho dosažení ochotny obětovat. Zároveň musely přehodnotit své původní (dnes označované jako naivní) představy o mateřství a své plány ohledně velikosti rodiny. Problematické jsou také věkové hranice, do nichž je ještě přijatelné o mateřství usilovat. Pro některé jsou stejně určující finanční limity, protože opakovaná léčba - byt' částečně hrazená ze zdravotního pojištění - je často nad jejich finanční možnosti. Mnoho žen se smírílo nebo smiřuje s tím, že jejich potomek nebude geneticky vlastní - za obtížněji přijatelnou je však považována varianta darované spermie než darovaného vajíčka. Důvody jsou dva: jejich partneři jsou častěji proti první možnosti, nebo i ženy samy nedovedou přijmout fakt, že by dítě neměly s mužem, kterého si dle svých slov vybraly právě proto, že se jim jevil jako ten nejvhodnější biologický otec.

Dana je matkou adoptivnímu chlapci a s manželem právě dávají žádost o druhé adoptivní dítě, Mirka i Linda už na takové dítě čekají. Žádost o adopci by zvážily nebo aktuálně zvažují téměř všechny konverzační partnerky - funguje ale jako poslední řešení, pojistka jistoty, že nezůstanou bezdětné. Paralelně s žádostí o adopci probíhají i pokusy o početí skrze asistovanou reprodukci. V případě, že je genetický základ rodičovství ohrožen, ženy zdůrazňují jiné aspekty rodičovského vztahu, tak jako Vendula, která se připravuje na mateřství díky darovanému vajíčku:

Uvažovala jsem nad adopcí, ale říkala jsem si, takhle bych to dítě aspoň nosila, a když to dítě nosím, tak mi doktor říkal, že jsem padesátiprocentní matka. Moje geny mít nebude, mám strach, že se jednou něco stane, že budou tomu dítěti muset něco transplantovat [...]. Ale ten vztah k tomu dítěti si určitě utvořím, když ho budu nosit. (Vendula)

I adoptivní rodičovství dává člověku možnost předat své životní zkušenosti a smysluplně naplnit život, což je podle konverzačních partnerek jeden z hlavních motivů jejich touhy po dítěti a u některých z nich také důvodem, proč odmítají pro ně krajní metody asistované reprodukce, jakými je využití pohlavních buněk dárce či dárkyně.

Partner hrál v situaci aktérek výzkumu klíčovou úlohu často, nejen když se jednalo o jeho sníženou plodnost jako hlavní príčinu problémů s početím. Pokud si ženy našly svého životního partnera až po třicítce, do procesu léčby vstoupily ve věku, kdy je její úspěšnost nižší a času na zkoušení málo (bez ohledu na to, na čí straně byla konkrétní príčina). Někdy 
muž fungoval jako „brzda“ mateřských plánů ženy - pokud byl napríklad (zatím) ženatým milencem, nebo několikanásobným otcem, který o rodičovství s novou partnerkou neměl prvních několik let jejich vztahu zájem. Obecně zastávali partneři žen v procesu léčby výrazně pasivní úlohu, kterou konverzační partnerky zdůvodňovaly jejich menší touhou po dítěti, větši ochotou smiŕit se s bezdětným životem nebo skutečností, že na rozdíl od žen není jejich plodnost tolik ovlivněna věkem. Jana popsala své neshody s partnerem ohledně žádosti o adopci a období krize, kterou jejich vztah v určité fázi procházel:

U nás nastal půl rok, tři čtvrtě roku domácího boje, kdy jsme se hádali, protože Martin se nemohl smířit s tou adopcí, já jsem ř́kala, bez dětí nechci být. Samožrejmě adopci necháváme až na konec, ale chci to dítě. A tehdy vlastně jsem mu otevřeně řekla, bud' do toho se mnou půjdeš do finále, nebo spolu nemusíme být, protože o tom život není, aby pak lidi žili vedle sebe bez dětí. (Jana)

Vendula zůstává se svým manželem i přes vážné problémy v jejich vztahu a pochybnosti o jeho zodpovědném přístupu $\mathrm{k}$ rodičovství - nechce už podruhé zažít situaci, kdy se v pořadníku žadatelek o darované vajičcko (pro ni jediný způsob, jak dosáhnout početí), dostane na první místo, ale kvůli tomu, že je rozvedená, léčbu nemůže podstoupit. Většina konverzačních partnerek však označila svůj vztah (který obvykle popisovaly jako kvalitní a prověřený krizemi souvisejícími s neplodností) za důležitější než mateřství. Několik z nich však připouštělo, že pokud by snaha o početí byla i dále neúspěšná a s partnerem by se neshodli na dalším postupu (umělé oplodnění s využitím dárce, adopce), zvažovaly by rozchod.

Romana už se smírila s tím, že dítě nebude mít se stálým partnerem a že její cesta za ním je velmi komplikovaná - přemýšlí, že umělé oplodnění dárcem uskuteční v zahraničí. Podobně jako Vendula se cítí být diskriminovaná českým právním řádem který jí jako svobodné matce neumožňuje mít dítě pomocí umělého oplodnění. Na radu lékaře, aby dítě počala s náhodným partnerem, reagovala takto:

Nejsem na to zvyklá, mně to přijde strašně pod úroveň. Podle mě je mnohem jednodušší, čistší a bezpečnější, je lepší dojít k lékaři, od toho je tady ten systém dárců a tak dál. [...] Oni mi řekli, nemáte právo tomu dítěti upírat otce a finanční pomoc. Což mi přijde nelogické, už z toho hlediska, že nikdo nemůže vyloučit [rozchod], do budoucnosti nikdo nevidí, kolik je dneska rozvedených lidí a matek, které ho [partnera] měly a nepomáhá jim. (Romana)

Pro některé konverzační partnerky by byla cesta $\mathrm{k}$ dítěti mnohem snazší, kdyby se pro něj rozhodly dřív - at' už proto, že byly mladší, nebo proto, že měly jiného partnera, který neměl problémy s plodností jako ten nynější. Období úzkostlivého bránění početí nebo strachu z otěhotnění, které některé dříve prožívaly, jim dnes přijde jako paradoxní. Vyslovují však nejistotu nad tím, zda by dnes jednaly jinak, nebo zda něčeho litují, podobně jako Barbora:

Možná bych měla dítě $\mathrm{s}$ kýmkoli, $\mathrm{v}$ jakékoli situaci, ale já vím, že jsem $\mathrm{v}$ životě udělala nějaké volby, že byl čas na kariéru, ted’ už čas na kariéru není, ted' je čas na rodinu a děti. (Barbora)

Zároveň však přiznává, že svým kamarádkám radí, aby dítě měly co nejdřív, s jakýmkoli partnerem, nebo i bez něj, protože ve chvíli, kdy se dozví o zdravotních problémech, může být na jejich řešení už pozdě. Podobně Mirka zpochybňuje svoje někdejší představy o vhodném věku k rodičovství: 
Člověk říká, tak nejdř́iv nějakou tu školu, pak práci, pak ještě cestovat a odmala jsem slýchala, že ta, co měla dítě v osmnácti, si zkazila život [...]. Takový model jsem slyšela nebo měla. [...] Já určitě nebudu dítěti říkat, měj dítě až po třiceti, až vystuduješ, spíš budu ř́kat, když budeš mít miminko, budu ráda, pomůžu ti, prostě se ten názor trošku změní, člověk vidí, že když chci ve třiceti, tak to neznamená, že to bude ihned. (Mirka)

Zpětně však většina konverzačních partnerek (včetně citované Mirky) říká, že i kdyby o svých zdravotních problémech (nebo o problémech partnera) věděly dř́ve, situaci by reálně nemohly př́liš ovlivnit. At' už proto, že svého partnera potkaly v pozdějším věku a nechtějí se vzdát mateřství vzešlého z fungujícího partnerského vztahu, anebo proto, že jejich problémy s věkem nesouvisí, nebo o mateřství začaly usilovat v době, kterou - i retrospektivně považují za adekvátní.

\section{Závěr}

Současné životní dráhy jsou popisovány jako vysoce individualistické a proměnlivé, vyznačující se zaměnitelností a zvratitelností jednotlivých fází (Holstein a Gubrium 2007; Elder, Johnson a Crosnoe 2004). Tento jejich charakter může být obtížně slučitelný s mateřstvím, které je sice chápáno jako jedna z fází životní dráhy ženy, ale svou podstatou se zároveň od ostatních fází odlišuje. Mateřství je vymezeno skrze kulturní a sociální normy (definující správný věk matky a správnou podobu mateřství) a biologicky podmíněno (období reprodukční kapacity ženy je omezené).

Jako problematická nebo potenciálně blokující mateřství se jeví nejen obecná společenská tendence směrem $\mathrm{k}$ individualizaci, ale také zvyšující se závislost jedince na komplexních sociálních a ekonomických strukturách, zdůrazňovaná teoretiky „pozdní modernity“ (např. Beck, Giddens a Lash 1994). V našem výzkumu to bylo zjevné v důrazu, který konverzační partnerky kladly na nabytí pracovních zkušeností a určité pozice na pracovním trhu před tím, než se stanou matkami. Směřování $\mathrm{k}$ individualizaci se zde prolíná $\mathrm{s}$ existenční nutností (i když odkaz na ni může být zpětnou legitimizací př́ípadného prodlužování této životní fáze).

Přechod k mateřství komplikuje také možný nesoulad v časování jednotlivých fází ženských a mužských životních drah. Zatímco ženám se pro vstup do rodičovské fáze nabízí omezený čas, muži mohou rodičovství umístit, přesně v intencích současné podoby životních drah, do libovolné životní fáze, prípadně jej - s menšími společenskými sankcemi ve srovnání se stejnou volbou žen - zcela pominout (Miall 1994, Monach 1993). Hledání partnera vhodného a ochotného $\mathrm{k}$ založení rodiny označovaly ženy z obou analyzovaných skupin jako jednu z podstatných, ale také problematických životních etap, které mateřství (případně snahám o jeho realizaci) předcházely.

Věková norma mateřství - v interakci s biologickými limity ženské reprodukce - určuje nejen dobu, kdy je na mateřství př́liš pozdě, ale také věk, který je pro mateřství př́iliš časný (Hašková a Zamykalová 2007, Bartošová 2007). Konverzační partnerky určovaly věk, ve kterém žena většinou ještě není na mateřství prípravena a dobu, kdy naopak už je mateřství prílišs rizikové (z hlediska sociálního i biologického). Připravenost ženy na mateřství je určená její dostatečnou seberealizací v jiných oblastech života (práce, společenský život, koníčky) a sub- 
jektivně vnímanou zralostí. Může to souviset s anticipovanou radikální proměnou jejího životního stylu následkem intenzivní péče o dítě během prvních let jeho života, která je v českém prostředí součástí normy správného mateřství (Hašková a Zamykalová 2007). Konverzační partnerky z obou výzkumů zmiňovaly osobní, profesní, př́ípadně vztahové zrání, které předcházelo rozhodnutí stát se matkou a zpětně bylo chápáno také jako největší výhoda mateřství ve vyšším věku. Konkrétní podoba jejich snahy o mateřství ale ukázala, že seberealizace v profesních a osobních aspektech života, která je nejen legitimní, ale jako př́íprava na pozdější pečovatelskou fázi také nezbytná, může tranzici $\mathrm{k}$ mateřství paradoxně komplikovat. Například samostatné bydlení mladých singles je popisováno jako významná součást individualizačního habitu, který brání posunu do rodinné fáze života (Tomášek 2006b). Podobným př́padem může být budování kariéry - ekonomicky nezávislá zralá žena na sňatkovém trhu naráží na nedostatek partnerů, kteř́ by se jí vyrovnali v samostatnosti a profesní kariére, a zároveň v touze po rodičovství. Prodlužování této „seberealizační“ životní fáze až k hranici ženského reprodukčního zdraví může vyústit $\mathrm{v}$ nedobrovolnou bezdětnost, případně rezignaci na původní rodinné plány.

Konverzační partnerky identifikují v rámci svých životních drah zlomové období, které bylo charakteristické intenzivní touhou po mateřství a obvykle bylo situováno kolem třiceti let věku. V kontrastu s předchozí životní fází, určovanou bezstarostností a nezávislým životním stylem se žena, bez ohledu na to, jak je jí mateřství reálně vzdáleno, začíná snažit překonat jeho př́ípadné překážky. Těmi mohou být absence vhodného a perspektivního partnerského vztahu, nebo zdravotní problémy. Určující pro tuto snahu je intenzita touhy po mateřství, vliv vrstevnické skupiny, vědomí zvyšujícího se věku a předpoklad fyzických, psychických i sociálních komplikací souvisejících $\mathrm{s}$ mateřstvím v pozdním věku. Nutnost návratu k životnímu stylu příznačnému pro životní fázi předcházející tomuto období (at' už ve snaze najít si partnera, nebo ve snaze zaplnit čas v př́ípadě prodlužovaní nechtěné bezdětnosti) jsou hodnoceny negativně. Období, kdy ženy začínají reálně uvažovat o mateřství, je zároveň dobou proměny obecnějších životních postojů a názorů. Nabyté životní zkušenosti vedou $\mathrm{k}$ úvahám o konečnosti vlastního života, a s tím související snahou dát mu hlubší smysl. Z výpovědí konverzačních partnerek je patrné, že mateřství chápou jako nový druh seberealizace, který umožňuje předat své životní zkušenosti a zažít nenahraditelný vztah matky k dítěti.

Jedním z našich hlavních výzkumných zájmů bylo popsat, jak ženy, jejichž tranzice $\mathrm{k}$ mateřství byla nebo je $\mathrm{z}$ různých důvodů problematická, pracují s normou správného mateřství. Analyzovaly jsme výpovědi žen, které o mateřství usilovaly nebo jej dosáhly, takže skutečnost, že obecnou normu mateřství jako pevnou součást ženské role většinou nezpochybňovaly, není překvapivá. Přestože některé z nich si dovedly představit bezdětný život, obvykle mu mateřství jasně nadřazovaly. Ve vztahu k věkovým normám byla patrná odlišnost našich dvou výzkumných skupin. Ženy, léčící se pro neplodnost, popisovaly vliv věkových norem na jejich situaci jako velmi silný. Souvisí to patrně s jejich intenzivnějším kontaktem s lékařskou profesí a statistikami vypovídajícími o snižující se plodnosti (a také úspěšnosti asistované reprodukce) ve spojitosti se zvyšujícím se věkem žen. Ženy z obou výzkumů ale lékařskou normu týkající se správného věku mateřství konfrontovaly s jinými definicemi - subjektivní, která vypovídá o tom, jak ony samy se cítí, nebo společenskou, která odráží 
demografické změny v české společnosti po roce 1989 (zejména zvyšující se věk vstupu do manželství a věk při porodu prvního dítěte).

Představy o vlastním mateřství zahrnovaly u žen z našeho výzkumu stabilní partnerský vztah a společné rozhodnutí o rodičovství jako jeho nezbytnou součást. Jako následek zralosti, zkušeností i zvyšujícího se věku a touhy po dítěti byla patrná určitá rezignace na původní kritéria výběru partnera. U žen z výzkumu „Nedobrovolná bezdětnost“ je zjevná také rezignace na původní představy o konkrétní podobě vlastního mateřství, zejména na přirozenost početí, biologickou vazbu k dítěti, vhodný věk pro zakládání rodiny a její velikost.

V našem výzkumu jsme se pokusily ukázat, jak spletité a nejednoznačné mohou být cesty k mateřství dnešních mladých žen, jak probíhá rozhodování o mateřství, jaké faktory, jevy a události volbu stát se matkou umožňují, nebo naopak blokují. Obecně sdílené představy o správném mateřství na jedné straně a otevřený prostor pro seberealizaci na straně druhé výrazně zužují nejvhodnější dobu pro vstup do mateřství. Následkem rozrůzněnosti životních voleb a stylů může i norma správného mateřství (v našem výzkumu především věková norma) podléhat postupným redefinicím a být oslabována $\mathrm{v}$ souvislosti $\mathrm{s}$ reálným chováním žen (a mužů).

\section{Literatura}

BAILEY, Lucy. Refracted Selves? A Study of Changes in Self-Identity in the Transition to Motherhood. Sociology, 1999, roč. 33, č. 1, s. 335-352. ISSN 0038-0385.

BARTOŠOVÁ, Michaela. Životní dráhy prvorodiček po třicítce: proč mít dítě později? Gender, rovné př́ležitosti, výzkum, 2007, roč. 8, č. 2, s. 75-81. ISSN 1213-0028.

BAUMAN, Zygmunt. The Individualized Society. Cambridge : Polity Press, 2001. 272 s. ISBN 074562507X.

BECK, Ulrich. Riziková společnost. Na cestě $k$ jiné moderně. 1. vyd. Praha : Slon, 2004. 431 s. ISBN 80-8642-932-6.

BECK, Ulrich ; GIDDENS, Anthony ; LASH, Scott. Reflexive Modernization: Politics, Tradition and Aesthetics in the Modern Social Order. 1. vyd. Cambridge : Polity Press, 1994. 225 s. ISBN 0804724725.

BECK, Ulrich ; Beck-Gernsheim, Elisabeth. The normal chaos of love. 1. vyd. Cambridge : Polity Press, 1995. 231 s. ISBN 0745613829.

BERGER, Peter L. ; LUCKMANN, Thomas. Sociálni konstrukce reality. 1. vyd. Brno : CDK, 1999. ISBN 8085959461.

EARLE, Sarah ; LETHERBY, Gayle. Conceiving Time? Women Who Do or Do not Conceive. Sociology of Health and Illness, 2007, roč. 29, č. 2, s. 233-250. ISSN 0141-9889.

ELDER, Glen H., Jr. Models of the Life Course. Contemporary Sociology, 1992, roč. 21, č. 2, s. 632-635. ISSN 0094-3061.

ELDER, Glen H., Jr. ; JOHNSON, Monica K. ; CROSNOE, Robert. The Emergence and Development of the Life Course Theory. In MORTIMER, J. T., SHANAHAN, M. J. (eds.) Handbook of the Life Course. 1. vyd. New York : Plenum, 2004. ISBN 0387324577.

ERIKSON, Erik H. Identity and the Life Cycle. New York: W. W. Norton \& Company, 1994. 191 s. ISBN 0393311325. 
GIDDENS, Anthony. Modernity and Self-identity: Self and Society in the Late Modern Age. 1. vyd. Cambridge : Polity Press, 1991. 256 s. ISBN 0745608892.

Gubrium, J., Holstein, J. 1997. The New Language of Qualitative Metod. New York : Oxford University Press.

HAGESTAD, Gunhild O. ; CALL, Vaughn R. A. Pathways to Childlessness. A Life Course Perspective. Journal of Family Issues, 2007, roč. 28, č. 10, s. 1338-1361. ISSN 0192-513X.

HAŠKOVÁ, Hana ; ZAMYKALOVÁ, Lenka. Mít děti - co je to za normu? Č́ je to norma? Biograf. 2006, č. 40-41, s. 3-53. ISSN 1211-5770.

HENDL, Jan. Úvod do kvalitativního výzkumu. 1. vyd. Praha : Karolinum, 1997. 243 s. ISBN 80-7184-549-3.

HOLSTEIN, James A.; GUBRIUM, Jaber F. Constructionist Perspectives on the Life Course. Sociology Compass, 2007, č. 1, s. 1-18. ISSN 1751-9020.

HUNT, Stephen. The Life Course: a Sociological Introduction. New York : Palgrave Macmillan, 2005. 240 s. ISBN 1403914702.

IRELAND, Mardy S. Reconceiving Women. Separating Motherhood from Female Identity. 1. vyd. New York : The Guilford Press, 1993. 195 s. ISBN 0898620163.

KAMMEYER, Kenneth; GINN, Helen. An Introduction to Population. Chicago : The Dorsey Press, 1986. 336 s. ISBN 0-256-03446-X.

LA ROSSA, Ralph ; SINHA, Cynthia. B. Constructing the Transition to Parenthood. Sociological Inquiry, 2006, roč. 76, č 4, s. 433-457. ISSN 0038-0245.

MAHER, Jane ; Saugeres, Lise. To Be or not to Be a Mother. Journal of sociology, 2007, roč. 43, č. 1, s. 5-21. ISSN 1440-7833.

MAREŠ, Petr. Co znamená mateřství. Sedmá generace, 2002, roč. 11, č. 10, s. 30-39. ISSN1212-0499.

MEYERS, Diana T. The Rush to Motherhood - Pronatalist Discourse and Women's Autonomy. Signs, 2001, roč. 26, č. 3, s. 735-773. ISSN 0097-9740.

MIALL, Charlene E. Community Constructs of Involuntary Childlessness: Sympathy, Stigma, and Social Support. Canadian Review of Sociology and Antropology, 1994, roč. 31, č. 4, s. 392-421. ISSN 0008-4948.

MILLER, Tina. Making Sense of Motherhood: A Narrative Approach. New York : Cambridge University Press, 2005. 184 s. ISBN 0521835720.

MONACH, James H. Childless: No Choice: The Experience of Involuntary Childlessness. London : Routledge, 1993. 288 s. ISBN 0415040906.

OAKLEY, Ann. Woman Confined: Towards a Sociology of Childbirth. Oxford : Martin Robertson, 1980. 334 s. ISBN 0805237437.

SANDELOWSKI, Margarete ; HOLDITCH-DAVIS, Diane ; HARRIS, Betty. G. Living the Life: Explanations of Infertility. Sociology of Health and Illness, 1990, roč. 12, č. 2, s. 195-215. ISSN 0141-9889.

SEVÓN, Eija. Timing Motherhood: Experiencing and Narrating the Choice to Become a Mother. Feminism and Psychology, 2005, roč. 15, č. 4, s. 461-482. ISSN 0959-3535.

SOBOTKA, Tomáš. Bezdětnost v České Republice. In HAMPLOVÁ, D., ŠALAMOUNOVÁ, P., ŠAMANOVÁ, G. (eds.). Životní cyklus. Sociologické a demografické perspektivy. 1. vyd. Praha : Sociologický ústav AV ČR, 2006. 308 s. ISBN 80-7330-082-6. 
TOMÁŠEK, Marcel. Singles a jejich vztahy; kvalitativní pohled na nesezdané a nekohabitující jednotlivce v České republice. Sociologický časopis, 2006, roč. 42, č. 1, s. 81-105. ISSN 0038-0288.

TOMÁŠEK, Marcel. K genderovým zdrojům individualizačního habitu. Gender, rovné přiležitosti, výzkum, 2006, roč. 7, č. 1, s. 75-81. ISSN 1213-0028.

VAN WISSEN, Leo J. G. ; DYKSTRA, Pearl A. (eds.) Population Issues. An Interdisciplinary Focus. 1. vyd. New York: Plenum Publishers, 1999. 292 s. ISBN 030646196X.

WENGRAF, Tom. Qualitative Research Interviewing: Biographic Narrative and Semi-structured Methods. 1. vyd. London: Sage Publications, 2001. 424 s. ISBN 0803975007.

\section{Autorky}

Michaela Bartošová je odbornou pracovnicí Institutu pro výzkum reprodukce a integrace společnosti při Fakultě sociálních studií Masarykovy univerzity v Brně. Zde také studuje doktorský studijní program na katedře sociologie. $\mathrm{K}$ jejím odborným zájmům $\mathrm{v}$ oblasti sociologie rodiny patří problematika časování mateřství, bezdětnosti a singles.

Kontakt: bartosov@fss.muni.cz

Lenka Slepičková je studentkou doktorského studijního programu sociologie na Fakultě sociálních studií Masarykovy univerzity a výzkumnou pracovnicí v Institutu pro výzkum reprodukce a integrace společnosti při téže fakultě. Zabývá se problematikou nedobrovolné bezdětnosti, neplodnosti a asistované reprodukce.

Kontakt: slepicko@fss.muni.cz 